\title{
Allometric height-diameter equations for Pinus pseudostrobus Lindl
}

\section{Ecuaciones locales de altura-diámetro para Pinus pseudostrobus Lindl}

\author{
Jonathan Hernández-Ramos ${ }^{1 *}$, J. Jesús García-Magaña ${ }^{2}$, Adrián Hernández-Ramos ${ }^{3}$, Xavier García-Cuevas ${ }^{1}$, \\ G. Geraldine García-Espinoza ${ }^{4}$, H. Jesús Muñoz-Flores ${ }^{1}$, J. Trinidad Sáenz-Reyes ${ }^{1}$ \\ ${ }^{1}$ Instituto Nacional de Investigaciones Forestales, Agrícolas y Pecuarias (INIFAP). Km 25 Carretera Bacalar-Chetumal, CP. \\ 77900, Chetumal, Quintana Roo, México \\ ${ }^{2}$ Universidad Michoacana de San Nicolás de Hidalgo, Avenida Francisco J. Múgica s/n, Ciudad Universitaria, CP. 58030 , \\ Morelia, Michoacán, México. \\ ${ }^{3}$ Colegio de Postgraduados, Montecillo, CP. 56230, Estado de México, México. \\ ${ }^{4}$ Universidad Autónoma de Nuevo León. Pedro de Alba s/n, Ciudad Universitaria, San Nicolás de los Garza, Nuevo León, \\ México \\ *Autor de correspondencia: forestjonathanhdez@gmail.com
}

Scientific article received: June 16, 2016 accepted: July 27, 2017

ABSTRACT. Silvicultural practices used for forest management in the Indigenous Community of Nuevo San Juan Parangaricutiro (CINSJP for its initials in Spanish), Michoacan, Mexico, are important for the sustainability of its woodlands. For this purpose, techniques that provide reliable and current quantitative estimates are required. The aim was to fit an equation that describes the allometric relationship between total height and normal diameter (Th-nd) of Pinus pseudostrobus in the CINJSP forests. Data were obtained from P. pseudostrobus stands that have been managed with the Silvicultural Development Method (SDM) at different stages according to the current forest management program. The research area is between 2,200 and 2500 masl, has a temperate type C (w2) climate, and is located at southwest of the Purhépecha Plateau within the Trans-Mexican Volcanic Belt region. The sample size consisted of 169 total height-normal diameter (Th-nd) data pairs. Ten allometric models to evaluate the goodness of fit were tested, choosing three models based on the lowest values of the sum of square errors of prediction (SSE) and the root mean squared error (RMSE), the highest adjusted coefficients of determination and the significance of their parameters. The deviations of the models were smaller than $0.01 \mathrm{~m}$. The three-parameter equation $T h=K+\frac{38.06004}{1+6.033101 \exp (0.066439 d n)}$, proved to be statistically more stable than the rest, and it also shows deviations of less than one meter per tree and less than $1 \%$ for the entire population.

Key words: Allometry, forest inventories, forest management, Pinus pseudostrobus

RESUMEN. Las prácticas silvícolas empleadas para el manejo de los bosques en la Comunidad Indígena de Nuevo San Juan Parangaricutiro (CINSJP), Michoacán, México; son importantes para la sostenibilidad de sus áreas arboladas. Para ello, se requiere de técnicas que permitan realizar estimaciones cuantitativas confiables y precisas. El objetivo fue ajustar una ecuación que describa la relación alométrica entre la altura total y el diámetro normal $(A / t-d n)$ de Pinus pseudostrobus en los bosques de la CINJSP. Los datos provienen de rodales de $P$. pseudostrobus que han sido manejados con el Método de Desarrollo Silvicola (MDS) en diferentes etapas, de acuerdo con el programa de manejo forestal vigente. Los bosques bajo estudio se encuentran entre los 2200 y $2500 \mathrm{msnm}$, con clima templado tipo C $\left(w_{2}\right)$, y se ubican al sur-occidente de la Meseta Purhépecha en el Eje Neovolcánico Transversal. El tamaño de muestra fue de 169 pares de datos de Alt-dn. Se analizaron diez modelos alométricos para evaluar su eficiencia en la predicción, eligiendo tres con base a los valores menores de la suma de cuadrados del error y la raíz del cuadrado medio del error, el mayor coeficiente de determinación ajustado y la significancia de sus parámetros. La distribución fue normal y los residuales sin problemas de heterocedasticidad. Las desviaciones de los modelos fueron menores a $0.01 \mathrm{~m}$. La ecuación: $A l t=K+\frac{38.06004}{1+6.033101 \exp (0.066439 d n)}$, de tres parámetros demostró ser estadísticamente más estable, además presenta desviaciones menores a un metro por árbol e inferior a $1 \%$ para toda la población.

Palabras clave: Alométria, inventarios forestales, manejo forestal, Pinus pseudostrobus 


\section{INTRODUCTION}

Temperate forests in Mexico cover 21\% of the country's area (Guzmán-Mendoza et al. 2014), with the genera Pinus and Quercus genus having the highest distribution (Sánchez-González 2008). The genus Pinus is composed of 40 endemic species in the country of the 100 reported worldwide (Alba-López et al. 2003), with the species where $P$. patula, P. oocarpa, P. pseudostrobus, $P$. herrerae, $P$. leiophylla and $P$. arizonica having have the greatest presence and commercial interest (Ramírez-Herrera et al.,2005). The species $P$. pseudostrobus stands out in importance for the forest industry in Michoacán state due its abundance and high productivity (García and González et al. 2003). In the Indigenous Community of Nuevo San Juan Parangaricutiro (CINSJP), the species $P$. Pseudostrobus, $P$. devoniana, P. leiophylla and $P$. montezumae are the most important in supplying raw material for sawmilling (MedinaGarcía and Guevara-Ferer 2000). In the CINSJP, Pinus pseudostrobus stands out in the sustainable management of its forests, with use and yield in an upward trend since 1979, the year in which the first forest management program was implemented (Castellano-Acuña et al. 2013).

The evolution of forest areas over time, as a consequence of management activities in a forest (Hernández-Díaz et al.,2008), causes dynamic changes in the structure, density and tree composition of the stands (Velasco et al. 2006). Estimating allometric relationships in trees reduces the field data collection time required for a forest inventory and helps obtain reliable estimates of variables that are difficult to measure, such as total height $(T h)$, which serves to estimate other variables, such as volume, biomass or carbon, through easy-tomeasure variables (Quiñonez et al. 2012), which are used in the planning of silvicultural activities for forest management programs (Hernández et al. 2016, García-Cuevas et al. 2016).

Total height is a basic variable in the classification of forest areas, as it helps to determine their productive capacity and consequently the stand de- limitation of the forest mass (Vanclay 1994). But in the data collection for a forest inventory, this variable is not measured in all trees, due to its degree of difficulty, in addition to the cost and time that this requires, so for the preparation of management plans this variable is estimated in a sub-sample measured per site (Zhang et al. 2002). Because of the importance of reducing time and costs in forest inventory data collection and the accurate estimation of the total height of trees for the preparation of forest management plans, in addition to the lack of quantitative tools to support the planning and implementation of management programs for this species, the aim was to fit an equation that describes the functional relationship between the total height and normal diameter of Pinus pseudostrobus in forests of the Indigenous Community of San Juan Nuevo Parangaricutiro, Michoacán.

\section{MATERIALS AND METHODS}

The study was conducted in a 520 ha area divided into six Pinus pseudostrobus stands under forest management, where the silvicultural development method (SDM) is applied, in accordance with the forest management program in force in the CINSJP. The forests are between 2200 and 2500 meters above sea level, where there is a humid temperate climate $\left(C\left(w_{2}\right)(b)\right.$ and $\left.C\left(w_{2}\right)(w)\right)$, and are located at southwest of the Purhépecha Plateau within the Trans-Mexican Volcanic Belt region (Velázquez et al. 2003).

In order to collect the field data, we took into account the procedure described by Laar and Akca (2007), who mentioned that information should be obtained from between 20 and 25 individual trees of all dimensions per stand to adequately cover the variability of each of the studied stands. By means of a directed sample, an average of 28 trees were measured per stand, of which the total height $(T h)$ and the normal diameter $(d n)$ were recorded in a total of 169 trees. Specific characteristics were considered for the selection of individuals, such as: a circular and undamaged crown; a monopodic, straight stem undamaged by lightning or fire and 
Table 1. Allometric models used to fit Th-nd equations of $P$. pseudostrobus in the Indigenous Community of Nuevo San Juan Parangaricutiro, Michoacán, Mexico.

\begin{tabular}{ccc}
\hline No. & Expresión & Literatura \\
\hline$(1)$ & $T h=b_{0}+b_{1} d n+b_{2} d n^{2}$ & Pece et al. 2006, Juárez et al. 2007, Vibrans et al. 2015 \\
$(2)$ & $T h=\frac{d n^{2}}{b_{0}+b_{1} d n+b_{2} d n^{2}}+1.3$ & Pece et al. 2006, Juárez et al. 2007 \\
$(3)$ & $T h=k+\frac{d n^{2}}{\left(b_{0}+b_{1} d n\right)^{2}}$ & Pece et al. 2006, Juárez et al. 2007 \\
$(4)$ & $T h=k+b_{0}\left(\frac{d n}{b_{1}+d n}\right)$ & Huang et al. 1992 \\
$(5)$ & $T h=k+\left(\frac{d n^{2}}{\left(b_{0}+b_{1} d n\right)^{2}}\right)$ & Huang et al. 1992 \\
$(6)$ & $T h=k+\exp \left(b_{0}+b_{1} d n^{b_{2}}\right)$ & Huang et al. 1992 \\
$(7)$ & $T h=k+\frac{b_{0}}{1+b_{1} e x p\left(b_{2} d n\right)}$ & Huang et al. 1992 \\
$(8)$ & $T h=k+\frac{d n^{2}}{\left(b_{0}+b_{1} d n+b_{2} d n^{2}\right)}$ & Huang et al. 1992 \\
$(9)$ & $T h=k+b_{0} \exp \left(\frac{b_{1}}{d n+b_{2}}\right)$ & Huang et al. 1992, Trincado y Leal 2006 \\
$(10)$ & $T h=k+\left(\frac{b_{0}}{1+\frac{1}{b_{1}} d n^{b_{2}}}\right)$ & Huang et al. 1992, Trincado y Leal 2006 \\
\hline
\end{tabular}

$k=$ Height of $1.3 \mathrm{~m}$ where $d b h$ is taken; $b^{\prime} \mathrm{s}=$ Parameters to be estimated.

without malformation, and trees that were not subject to resin extraction or tapping activities. Stands were also excluded if they had pests, diseases or any type of natural or anthropogenic disturbance and if they were less than $20 \mathrm{~m}$ from roads or clearings to avoid edge effect problems.

We analyzed ten allometric models (Table 1 ) chosen for having shown good estimates in other works (Huang et al. 1992, Pece et al. 2006, Trincado and Leal 2006, Juárez et al. 2007 and Vibrans et al. 2015), in which $\mathrm{k}=$ height of $1.3 \mathrm{~m}$ where dbh is taken; b's = Parameters to be estimated. In choosing the equations, we considered the recommendations made by Fang and Bailey (1998) who suggest using only two- and threeparameter models, because expressions with four or more can lead to problems of convergence or instability of the estimates. The fit of the models and the estimation of their parameters were performed with the MODEL procedure, which is an indistinct procedure for linear and non-linear models, and the SAS (SAS 2008) FIML method. To obtain a better convergence of the parameters, we used initial values obtained by Huang et al. (1992), Pece et al. (2006), Trincado and Leal (2006), Juárez et al. (2007), Vibrans et al. (2015), as suggested by Milena et al. (2013).

The goodness of fit of the models was determined by the lowest values of the sum of the mean squared errors of prediction (SSE) and the root mean squared error (RMSE) (Trincado and Leal 2006, Vibrans et al. 2015) and the highest values of the adjusted coefficient of determination $\left(\mathrm{R}_{2 a d j}\right)$, as well as the significance of the parameters and the low values in their standard error (Diéguez-Aranda et al. 2005). The homoscedasticity assumptions of the residuals were evaluated with the graphic analysis and the White (W) test, the autocorrelation of errors using the Durbin-Watson (DW) test (Barrios et al. 2014) and the normality with the Shapiro-Wilk (SW) test (Vibrans et al. 2015), considering the Kurtosis index (KI) (Martínez-López and Acosta-Ramos 2014). The accuracy of the estimates was evaluated with the absolute bias (B), the aggregate difference in percentage (AD \%) (Lencinas and Mohr-Bell 2007) and the graphical test of predicted data against observed data.

\section{RESULTS}

The descriptive statistics indicate the range of applicability of the adjusted equations, in which the normal diameter averages $35.82 \mathrm{~cm}$ with variation of 10 to $65 \mathrm{~cm}$, and height averages $24.52 \mathrm{~m}$ with values lowerand greater than 7.50 to $39.00 \mathrm{~m}$; the variance describes the dispersion of the data used for the fit, together with the values of the coefficient of variation (CV) and standard deviation (Table 2).

For the regressions, the results of the fit show an explanation of the variation of the data above 
Table 2. Descriptive statistics of the sample used of $P$. pseudostrobus in the Indigenous Community of Nuevo San Juan Parangaricutiro, Michoacán, Mexico.

\begin{tabular}{ccccccc}
\hline Variable & Average & Maximum & Minimum & Variance & Standard deviation & Coefficient of Variation \\
\hline$d n$ & 35.82 & 65 & 10 & 263.5825 & 16.2352 & 45.3302 \\
$T h$ & 24.52 & 39 & 7.5 & 76.0307 & 8.7196 & 35.5641 \\
\hline
\end{tabular}

Table 3. Fit statistics and parameter values of the allometric Th-dbh models for $P$. pseudostrobus in the Indigenous Community of Nuevo San Juan Parangaricutiro, Michoacán, Mexico.

\begin{tabular}{|c|c|c|c|c|c|c|c|c|}
\hline Model & $S C E$ & $R C M E$ & $R_{a d j}^{2}$ & Parameter & Estimate & $A S E^{*}$ & t-value & $\mathrm{pr}>\mathrm{t}$ \\
\hline \multirow[t]{3}{*}{ (1) } & 1206.5 & 2.7041 & 0.904 & $\mathrm{~b}_{0}$ & 1.160227 & 1.0979 & 1.06 & 0.2921 \\
\hline & & & & $b_{1}$ & 0.849674 & 0.0692 & 12.28 & $<0.0001$ \\
\hline & & & & $b_{2}$ & -0.00458 & 0.000944 & -4.85 & $<0.0001$ \\
\hline \multirow[t]{3}{*}{ (2) } & 1221.7 & 2.7211 & 0.903 & $b_{0}$ & 1.988528 & 2.1719 & 0.92 & 0.3612 \\
\hline & & & & $b_{1}$ & 0.98272 & 0.149 & 6.59 & $<0.0001$ \\
\hline & & & & $b_{2}$ & 0.012079 & 0.00217 & 5.55 & $<0.0001$ \\
\hline \multirow[t]{2}{*}{ (3) } & 1249.4 & 2.7434 & 0.901 & $\mathrm{~b}_{0}$ & 2.618767 & 0.0895 & 29.25 & $<0.0001$ \\
\hline & & & & $b_{1}$ & 0.127645 & 0.00232 & 55.1 & $<0.0001$ \\
\hline \multirow[t]{2}{*}{ (4) } & 1226.9 & 2.7186 & 0.903 & $\mathrm{~b}_{0}$ & 95.95421 & 8.522 & 11.26 & $<0.0001$ \\
\hline & & & & $b_{1}$ & 106.3844 & 13.1413 & 8.1 & $<0.0001$ \\
\hline \multirow[t]{2}{*}{ (5) } & 1249.4 & 2.7434 & 0.901 & $\mathrm{~b}_{0}$ & 2.618767 & 0.0895 & 29.25 & $<0.0001$ \\
\hline & & & & $b_{1}$ & 0.127645 & 0.00232 & 55.1 & $<0.0001$ \\
\hline \multirow[t]{3}{*}{ (6) } & 1228.2 & 2.7282 & 0.902 & $\mathrm{~b}_{0}$ & 5.369114 & 0.8144 & 6.59 & $<0.0001$ \\
\hline & & & & $b_{1}$ & -7.3061 & 0.4755 & -15.37 & $<0.0001$ \\
\hline & & & & $b_{2}$ & -0.33834 & 0.1216 & -2.78 & 0.006 \\
\hline \multirow[t]{3}{*}{ (7) } & 1186.4 & 2.6815 & 0.905 & $\mathrm{~b}_{0}$ & 38.06004 & 1.3558 & 28.07 & $<0.0001$ \\
\hline & & & & $b_{1}$ & 6.033101 & 0.4505 & 13.39 & $<0.0001$ \\
\hline & & & & $b_{2}$ & 0.066439 & 0.00481 & 13.82 & $<0.0001$ \\
\hline \multirow[t]{3}{*}{ (8) } & 1221.7 & 2.7211 & 0.903 & $b_{0}$ & 1.976307 & 2.1715 & 0.91 & 0.3641 \\
\hline & & & & $b_{1}$ & 0.983431 & 0.149 & 6.6 & $<0.0001$ \\
\hline & & & & $b_{2}$ & 0.012070 & 0.00217 & 5.55 & $<0.0001$ \\
\hline \multirow[t]{3}{*}{ (9) } & 1210.6 & 2.7087 & 0.904 & $b_{0}$ & 71.62702 & 7.9274 & 9.04 & $<0.0001$ \\
\hline & & & & $b_{1}$ & -55.04980 & 10.7782 & -5.11 & $<0.0001$ \\
\hline & & & & $b_{2}$ & 15.23139 & 4.4161 & 3.45 & 0.0007 \\
\hline \multirow[t]{3}{*}{ (10) } & 1217.1 & 2.716 & 0.903 & $\mathrm{~b}_{0}$ & 68.95959 & 15.4901 & 4.45 & $<0.0001$ \\
\hline & & & & $b_{1}$ & 0.008691 & 0.00139 & 6.27 & $<0.0001$ \\
\hline & & & & $b_{2}$ & 1.158101 & 0.1349 & 8.59 & $<0.0001$ \\
\hline
\end{tabular}

ASE*: Approximate Standard Error.

$90 \%\left(R^{2}{ }_{a d j}>0.9\right)$ with low SSE and RMSE values. But for models 1, 2 and 8, the reference parameter of the intercept is not significant, a situation that can cause problems in the estimation of total height, so they were ruled out of the final selection (Table 3). Models 7, 9 and 10 were the best, for having the lowest values in the SSE and RMSE, and the highest values of $R^{2}{ }_{a d j}$, in addition to presenting all their significant parameters and low standard errors, which makes them statistically stable in the prediction.

The graphical results of the evaluation of the regression assumptions for the three selected models indicate that there are no heterocedasticity problems, which is confirmed by the non-significance of the White test. The data tend towards normality because the SW test was greater than 0.94 , and the Kurtosis index and the tendency in the graph in all cases is leptokurtic. The Durbin-Watson autocorrelation statistic is below 1.5 and the likelihood statistic is very similar among the three models, with models 9 and 10 being superior to model 7 (Table 4).

The accuracy of the estimates made by the three models indicates that model 7 is the one that generates the lowest deviations when estimating, individually or in general terms, the total height from the diameter at breast height, followed by model 9 and finally model 10 , where none of them reaches $1 \%$ or the error meter when calculating the total height as a function of diameter at breast height (Table 5). In the graph of the predicted values 
Table 4. Tests of regression assumptions and likelihood statistic in the selected allometric Th-dbh models for P. pseudostrobus in the Indigenous Community of Nuevo San Juan Parangaricutiro, Michoacán, Mexico.

\begin{tabular}{ccccccccc}
\hline \multirow{2}{*}{ Model } & \multicolumn{2}{c}{ White's Test } & \multicolumn{2}{c}{ Shapiro-Wilk } & \multicolumn{2}{c}{ Kurtosis Index } & \multirow{2}{*}{ DW } & Log \\
\cline { 2 - 7 } & Value & Probability & Value & Probability & Value & Probability & & Lokelihood \\
\hline 7 & 6.32 & 0.5025 & 0.94 & 0.0001 & -2.12 & 0.0341 & 1.32 & -402.5783 \\
9 & 4.24 & 0.6441 & 0.95 & 0.0001 & -2.08 & 0.0377 & 1.41 & -404.275 \\
10 & 5.09 & 0.5325 & 0.95 & 0.0001 & -2.07 & 0.0385 & 1.43 & -404.7246 \\
\hline
\end{tabular}

against observed values, a desirable estimate tendency was found (Figure 1). Model 7 was selected as the best because it predicts the data trend with greater fidelity; unlike models 9 and 10, the height prediction curve does not decrease until $50 \mathrm{~cm}$ in diameter, overestimating the values of the dimensions.

Table 5. Bias and aggregate difference in $\%$ of the estimates made with three allometric Th-dbh models for P. pseudostrobus in the Indigenous Community of Nuevo San Juan Parangaricutiro, Michoacán, Mexico.

\begin{tabular}{lccc}
\hline Model & 7 & 9 & 10 \\
\hline Bias & -0.0010 & 0.0034 & 0.0114 \\
AD $\%$ & -0.0041 & 0.0138 & 0.0463 \\
\hline
\end{tabular}

\section{DISCUSSION}

The models 7, 9 and 10 chosen for their greater fit have an additive term, which causes the equations to have a diameter at breast height equal to zero when the height above the stem is equal to $1.3 \mathrm{~m}$, which according to Diéguez-Aranda et al. (2009) and Puji (2014) is reasonable from a theoretical point of view, because the prediction of total height in trees with diameters close to zero is of no interest. The regression assumptions are not violated, because the White test showed homoscedasticity of the residuals and the normality of the data evaluated with the Shapiro-Wilk test (MartínezLópez and Acosta-Ramos 2014), and the Kurtosis index according to the classification of Conesa et al. (2009) was of leptocurtic form in all three cases. This indicates that the information used is slightly loaded to the left of the Gauss bell-shaped graph (SAS 2008). The Durbin-Watson autocorrelation statistic was below 1.5, a situation similar to that reported by Fuentes et al. (2001a and 2001b) who indicate that a value of 1.4 implies that model errors are given by variables not included within it, but that they affect one of the independent variables.

The accuracy of the estimates was verified with Hair et al. (1999), who indicate that it is not always the most statistically stable equation that complies with the regression assumptions that generates better estimates or produces the least biases. The graph of the predicted values against observed values shows the trend of the estimates that are similar to those reported by Puji (2014) when using two linear and five non-linear models to represent the allometric relationship between the total height and diameter at breast height of tropical species. Model 7 was selected as the best because it predicts the data trend with greater fidelity, a situation similar to that reported by Juárez et al. (2007) and Puji (2014) who found that nonlinear models have a better fit.

The chosen model is different from the cubic linear model proposed by Hadaet (2014) to estimate height according to diameter in P. brutia and the models proposed by Huang et al. (1992) for species of the genera Picea, Pinus, Populus, Betula, Abies, Pseudotsuga and Larix. But the height curves generated with local allometric models are the most accurate in the estimates of forests or stands (Diéguez-Aranda et al. 2009). Model 7, selected for being more stable, presents the smallest deviations when estimating the total height according to diameter at breast height, and according to Costas and Rodríguez (2003) it can be used reliably in estimating height and other derived variables such as the volume of the stands or for the characterization of the structure of the tree masses of this species, 

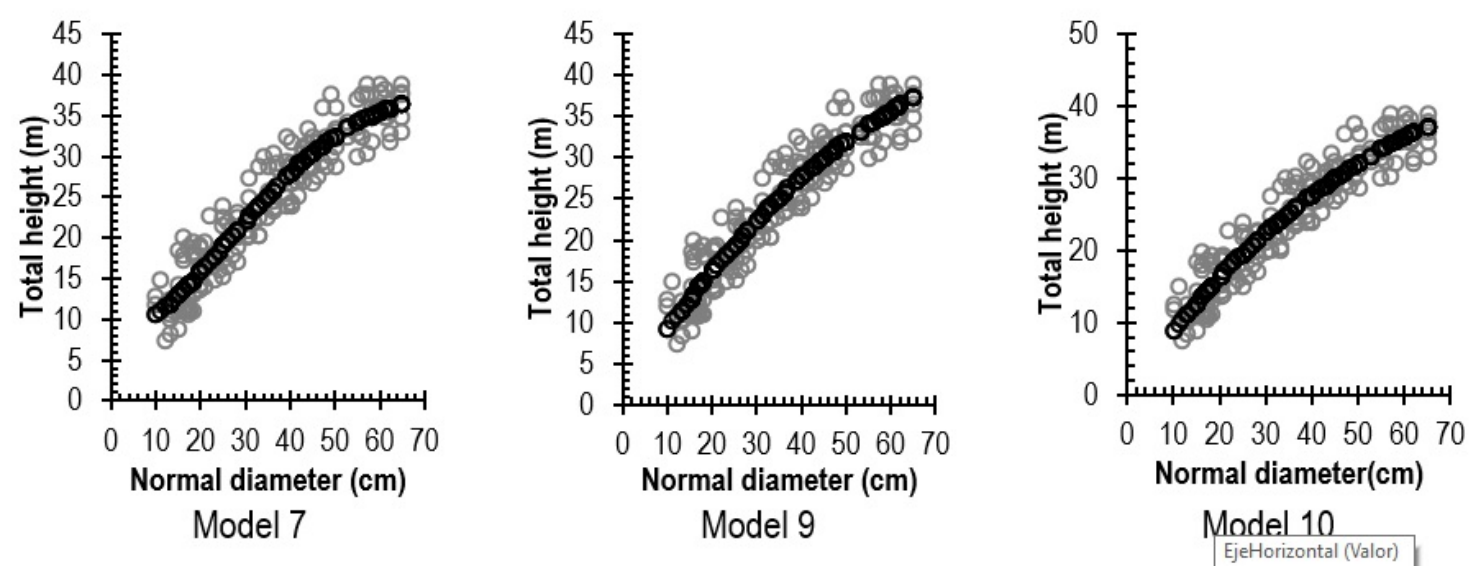

Figure 1. Trend of the predicted versus observed values of the three allometric Th-dbh models selected for $P$. pseudostrobus in the Indigenous Community of Nuevo San Juan Parangaricutiro, Michoacán, Mexico.

as well as for economizing on forest inventory costs (Trincado and Leal 2006). In addition, it can be included to project the growth of the species in a reliable way, as mentioned by Diéguez-Aranda et al. (2005).

This study's applicability is restricted to the local level (Diéguez-Aranda et al. 2009) despite the high pressure of such equations demonstrated by Trincado and Leal (2006), a situation by which the fitting of generalized height-diameter models, either traditionally or under the mixed-effects approach, is an alternative that extends the functionality of the information generated, reduces biases and better covers regional variability (Corral-Rivas et al. 2014, Kuliešis et al. 2014). Other similar works mention the goodness of fit of such results in the collection of field information and in the accuracy of the total height estimates to calculate the volume individually or by stand (Diéguez-Aranda et al. 2009, Vibrans et al. 2015).

\section{CONCLUSIONS}

The selected equations can be applied in the CISJNP's $P$. pseudostrobus forests to reduce the time spent conducting a forest inventory, to obtain the necessary field data to estimate the total volumetric stock in the stands or to characterize the vertical structure of the forests. Equation 7 proved to be more stable than the other equations, so it can be used reliably to estimate height. This can be part of the quantitative silvicultural methodologies for estimating the height and total volume of the stands, in addition to the growth and yield calculations by combining the results with stand variables.

\section{ACKNOWLEDGMENTS}

The authors thank the Indigenous Community of San Juan Nuevo Parangaricutiro and its technical staff for the use of their facilities and their willingness to collaborate in this research.

\section{LITERATURE CITED}

Alba-López MP, González-Espinosa M, Ramírez-Marcial N, Castillo-Santiago MA (2003) Determinantes de la distribución de Pinus spp., en la altiplanicie central de Chiapas, México. Boletín de la Sociedad Botánica de México 73: 7-15.

Barrios A, López AM, Nieto V (2014) Predicción de volúmenes comerciales de Eucalyptus grandis a través de modelos de volumen total y de razón. Colombia Forestal 17: 137-149. 
Castellanos-Acuña D, Sáenz-Romero RC, Lindig-Cisneros A, Sánchez-Vargas NM, Lobbit P, Montero-Castro JC (2013) Variación altitudinal entre especies y procedencias de Pinus pseudostrobus, $P$. devoniana y $P$. leiophylla. Ensayo de vivero. Revista Chapingo Serie Ciencias Forestales y del Ambiente 19: 399-411.

Conesa GC, Arana CR, García LR (2009) Variación granulométrica y mineralógica en profundidades de los sedimentos retenidos por diques. Estudio en cauces torrenciales semiáridos del sureste Peninsular. Nimbus 23-24: 61-88.

Corral-Rivas S, Álvarez-González JG, Crecente-Campo F, Corral-Rivas JJ (2014) Local and generalized heightdiameter models with random parameters for mixed, uneven-aged forests in Northwestern Durango, Mexico. Forest Ecosystems 1: 1-9.

Costas R y Rodríguez G (2003) Relaciones hipsométricas promedios para P. Elliotti Engl. Revista Yviraretá 12: $19-25$.

Diéguez-Aranda U, Alboreca RA, Castedo-Dorado F, Álvarez-González JG, Barrio-Anta M, Crecente-Campo F, et al. (2009) Herramientas selvícolas para la gestión forestal sostenible en Galicia. Xunta de Galicia. Lugo, España. 259p.

Diéguez-Aranda U, Barrio-Anta M, Castedo-Dorado F, Álvarez-González JG (2005) Relación altura-diámetro generalizada para masas de Pinus sylvestris L. procedentes de repoblación en el noroeste de España. Investigación Agraria. Sistemas y Recursos Forestales 14: 229-241.

Fang Z, Bailey LR (1998) Height-diameter models for tropical forests on Hainan island in southern China. Forest Ecology and Management 110: 315-327.

Fuentes ED, Troncoso JJ, Bonilla CA (2001a) Operaciones forestales y concentración de sedimentos en cauces naturales I: Formulación de un modelo matemático. Bosques 22: 15-24.

Fuentes ED, Troncoso JJ, Bonilla CA (2001b) Operaciones forestales y concentración de sedimentos en cauces naturales II: Análisis de sensibilidad y comparación con otros modelos. Bosques 22: 25-27.

García AA, González MS (2003) Pinaceas de Durango. Instituto de Ecología A.C. Comisión Nacional Forestal. México. 187p.

García-Cuevas X, Herrera-Ávila V, Hernández-Ramos J, García-Magaña JJ, Hernández Ramos J (2016) Ecuaciones para predecir el diámetro normal en función del diámetro del tocón para Abies religiosa (Kunth) Schltdl. et Cham. Revista Mexicana de Ciencias Forestales 7: 95-103.

Guzmán-Mendoza R, Zavala-Hurtado JA, Castaño-Meneses G, León-Cortés JL (2014) Comparación de la mirmecofauna en un gradiente de reforestación en bosques templados del centro occidente de México. Madera y Bosques 20: 71-83.

Hadaet OM (2014) Predictive models between diameter, height, Crown diameter and age of Pinus brutia Ten. In Zawita and atrush districs. Global Journal of Bio-Science and BioTechnology 3: 203-210.

Hair JF, Anderson RE, Tatham RL, Blach WC (1999) Análisis multivariante. Quinta edición. Prentice Hall Iberia. Madrid, España. 832p.

Hernández-Díaz JC, Corral-Rivas JJ, Quiñonez-Chávez A, Bacon-Sobbe JR, Vargas-Larreta B (2008) Evaluación del manejo forestal regular e irregular en bosques de la Sierra Madre Occidental. Madera y Bosques 14: 25-41.

Hernández RJ, García CX, García MJJ, Muñoz FHJ, Velarde RJC, Olvera DEH (2016) Factores de proporción y ecuaciones de diámetro normal a partir del tocón para Pinus greggii Engelm. Revista Mexicana de Ciencia Forestales 7: 7-18. 
Huang S, Titus JS, Wiens DP (1992) Comparison of nonlinear height-diameter functions for major Alberta tree species. Canadian Journal of Forest Research 22: 1297-1304.

Juárez GM, Pece MG, Gaillard BC, Sanguedolce J, Mariot V, Mazzuco R (2007) Ecuaciones altura-diámetro en Prosopis nigra (Griseb) Hieron (Algarrobo negro) en Santiago del Estero, Argentina. Foresta Veracruzana 9: 9-14.

Kuliešis A, Kulbokas G, Kuliešis AA (2014) Validation of generalized height-diameter model based on Lithuanian NFL data. Baltic Forestry 20: 287-300.

Laar AV, Akca A (2007) Forest mensuration. Managing forest ecosystems. Springer. Dordrecht, Netherlands. $382 \mathrm{p}$.

Lencinas JD, Mohr-Bell D (2007) Estimación de clases de edad de las plantaciones de la provincia de Corrientes, Argentina, con base en datos satelitales Landsat. Bosque 28: 106-118.

Martínez-López J, Acosta-Ramos A (2014) Estimación del diámetro, altura y volumen a partir del diámetro del tocón para Quercus laurina en Ixtlán, Oaxaca, México. Madera y Bosques 20: 59-70.

Medina-García C, Guevara-Ferer F (2000) Estudio florístico en el área de la Comunidad Indígena de Nuevo San Juan Parangaricutiro, Michoacán, México. Acta Botánica Mexicana 52: 5-41.

Milena LA, Trincado G, Barrios A, Nieto V (2013) Modelos regionales de altura-diámetro para plantaciones jóvenes de Eucalyptus tereticornis en la costa atlántica colombiana. Bosque 34: 233-241.

Pece MG, Benítez C, Juárez M, Mariot V, Sanguedolce J, Pranzoni O (2006) Modelación de la altura total para quebracho colorado santiagueño (Schinopsis quebracho-colorado). Foresta Veracruzana 8: 1-7.

Puji NN (2014) Relationship between total tree height and diameter at breast height for tropical peat swamp forest tree species in rokan hilir district, riau province. Indonesian Journal of Forestry Research 1: 89-107.

Quiñonez BG, Cruz CF, Vargas LB, Hernández FJ (2012) Estimación del diámetro, altura y volumen a partir del tocón para especies forestales de Durango. Revista Mexicana de Ciencias Forestales 3: 23-39.

Ramírez-Herrera C, Vargas-Hernández JJ, López-Upton J (2005) Distribución y conservación de las poblaciones naturales de Pinus greggii. Acta Botánica Mexicana 72: 1-16.

Sánchez-González A (2008) Una visión actual de la diversidad y distribución de los pinos de México. Madera y Bosques 14: 107-120.

SAS (2008) Statistical Analysis System, SAS/STAT $\mathbb{R} 9.2$ User's Guide Second Edition. SAS Institute Inc. Raleigh, NC USA. https://support.sas.com/documentation/cdl/en/statugmcmc/63125/PDF/default/ statugmcmc.pdf. Fecha de consulta: 21 de abril de 2016.

Trincado G, Leal DC (2006) Ecuaciones locales y generalizadas de altura-diámetro para pino radiata (Pinus radiata). Bosque 27: 23-34.

Vanclay J (1994) Modelling forest growth and yield: Applications to mixed tropical forests. CAB International. London, UK. 312p.

Velasco BE, Madrigal HS, Vázquez CI, González HA, Moreno SF (2006) Manual para la elaboración de tablas de volumen fustal en pino. Libro Técnico No. 1. INIFAP-CONACYT-CONAFOR. México. 34p.

Velázquez A, Bocco G, Torres A, Cortés G (2003) La vegetación, sus componentes y un análisis jerárquico del paisaje. En: Velázquez A, Torres A, Bocco G (Comp.). Las Enseñanzas de San Juan. INE-SEMARNAT. México. pp: 201-234. 
Vibrans AC, Moser P, Zimermann OL, Mazaneuro JP (2015) Height-diameter models for three subtropical forest types in Southern, Brazil. Ciência e Agrotecnologia 39: 205-215.

Zhang L, Peng C, Huang S, Zhou X (2002) Development and evaluation of ecoregion-based jack pine heightdiameter models for Ontario. Forestry Chronicle 78: 530-538. 
